\title{
WOKÓŁ POJĘCIA DEZINFORMACJI W ASPEKCIE PRAWNO-KRYMINALISTYCZNYM
}

\begin{abstract}
ABSTRAKT: Artykuł stanowi próbę przedstawienia zagadnienia dezinformacji w mass mediach oraz wpływu dezinformacji na społeczeństwo ze szczególnym uwzględnieniem aspektu prawno-kryminalistycznego tegoż pojęcia. W pierwszej części artykułu pojawia się analiza dotycząca samego pojęcia dezinformacji, a mianowicie pierwszego użycia tegoż słowa, jego znaczeń oraz zastosowania. W kolejnej części artykułu pojawiają się rozważania dotyczące stricte zagadnienia dezinformacji w mediach w aspekcie prawno-kryminalistycznym wraz z przywołaniem stosownych przykładów obrazujących dane zjawisko oraz ukazaniem wpływu na społeczeństwo. W świecie, gdzie środki masowego przekazu i opinia publiczna odgrywają bardzo ważną rolę, dezinformacja ma ogromną siłę sprawczą, także w sferze prawno-kryminalistycznej, na co wskazuje poniższa praca.
\end{abstract}

SŁOWA KLUCZOWE: dezinformacja, fake news, sprawy karne, art. 132 kk

\section{ON THE CONCEPT OF DISINFORMATION IN THE LEGAL AND FORENSIC ASPECT}

ABSTRACT: The article describes the issue of disinformation in the mass media and the impact of disinformation on society, with particular emphasis on the legal and forensic aspect of this concept. The first part of the article contains information about the very concept of disinformation, namely the first use of this word, its meanings and use. In the next part of the article, there are considerations strictly related to the issue of disinformation in the media in the legal and forensic aspect, together with the reference to relevant examples illustrating a given phenomenon and showing the impact on society. In a world where the mass media and public opinion play a very important role, disinformation has a huge driving force also in the legal and forensic sphere, as indicated in the article below.

KEYWORDS: disinformation, fake news, criminal cases, article 132 of the Penal Code

${ }^{1}$ Police Academy in Szczytno; Poland. 


\section{WPROWADZENIE}

Dzisiejsze społeczeństwo nazwać należy informacyjnym, gdyż informacje oraz dane niekiedy stają się towarem cenniejszym nawet niż dobra materialne. Szczególnie cenne są dane osobowe, stanowiące wystarczające informacje, jakie umożliwiają zidentyfikowanie danej osoby. W 2016 roku zostało wydane przez Unię Europejską ogólne rozporządzenie dotyczące ochrony i przetwarzania danych osobowych, które zostało odpowiednio implikowane przez poszczególne kraje europejskie. Dane osobowe oraz wszelkie inne informacje są tak istotne, gdyż mają moc kreowania rzeczywistości, a sposób ich przekazu jest w stanie modyfikować jej obraz. Wydaje się, że w dobie cyfryzacji społeczeństw, gdzie potężną siłę stanowią mass media, nazywane „czwartą władzą”, informacja nabiera bardzo dużego znaczenia. Wszędzie tam, gdzie pojawiają się informacje, przekaz oraz ich odbiorca, dochodzi do zniekształceń i zakłamań w tym procesie. Wówczas pojawia się także dezinformacja.

Wraz z pojęciem informacji pojawia się pojęcie dezinformacji. Pojęcie dezinformacji rozważane w aspekcie prawno-kryminalistycznym stało się tematem niniejszego artykułu. Celem niniejszego artykułu jest analiza pojęcia dezinformacji ze szczególnym odniesieniem do rzeczywistości prawno-kryminalistycznej oraz do roli tejże dezinformacji w mass mediach wraz z ukazaniem jej oddziaływania na społeczeństwo oraz przytoczeniem stosownych przykładów. Problemem badawczym staje się teoretyczne rozważanie, w jaki sposób w literaturze rozumiane jest pojęcie dezinformacji ze szczególnym zwróceniem uwagi na pojęcie dezinformacji $\mathrm{w}$ aspekcie prawno-kryminalistycznym w odniesieniu do przekazu wiadomości dezinformacyjnych do odbioru opinii publicznej za pośrednictwem mass mediów. Uściślając problemem badawczy, należy zadać pytania: W jaki sposób dezinformacja pojawia się w rzeczywistości prawno-kryminalistycznej? Jak jest rozumiana, przekazywana oraz oceniana?

Metodą badawczą wykorzystaną w niniejszym artykule jest metoda analizy i krytyki dostępnej literatury. Jak podaje dr Kalina Grzesiuk, metoda analizy i krytyki piśmiennictwa ,polega na przystosowaniu nowego problemu do wiedzy dotychczasowej”"2, w celu wykazania podobieństw, różnic, związków oraz zależności. Metoda ta została zastosowana w niniejszym artykule, gdzie odnosi się definicyjne pojęcie „dezinformacji” w ogóle do dezinformacji, jaka pojawia się w aspekcie prawno-kryminalistycznym w przekazie wiadomości do odbioru opinii publicznej za pośrednictwem mass mediów. Obok wyżej wymienionej metody w niniejszym artykule posłużono się także metodą analizy indywidualnych przypadków, gdzie analizuje się indywidualne przypadki osobowe, aby zrealizować postawiony sobie cel badawczy.

\footnotetext{
${ }^{2}$ K. Grzesiuk, Metodyka badań naukowych, [w:] https://pracownik.kul.pl/files/12359/public/grzesiuk/seminarium/metodyka_badan_naukowych.pdf (09.10.2021).
} 


\section{ROZUMIENIE POJĘCIA „DEZINFORMACJA"}

Analizując genezę pojęcia „dezinformacja” dostrzega się, że jest to słowo stosunkowo młode, gdyż po raz pierwszy zostało użyte w pierwszej połowie XX wieku. Biorąc pod uwagę rozwój ludzkości i jej historię bez wątpienia pojęcie „dezinformacji” można uznać za nowy wytwór językowy. W 1923 roku w Imperium Rosyjskim powstała instytucja rządowa - biuro dezinformacyjne, którego zadaniem było m.in. wprowadzanie w błąd w celu uzyskiwania określonych korzyści wizerunkowych, strategicznych, politycznych, finansowych, militarnych, itd. W Polsce pojęcie to pojawiło się po raz pierwszy w 1929 roku i zostało użyte w Instrukcji Oddziału II Sztabu Wojska Polskiego, gdzie „dezinformacja” polegała na przekazywaniu „wywiadowi przeciwnika wiadomości ukrywających własne zamierzenia oraz na zmuszaniu go do traktowania informacji podanej przez wywiad własny, jako prawdziwej, względnie zmuszaniu wywiadu obcego do analizy inspirowanych wiadomości przez czas dłuższy”’3.

Pojęcie ,dezinformacja” powstało poprzez przyłączenie przedrostka dez- do słowa ,informacja”. Jak wskazuje słownik języka PWN przedrostek dez- „wskazuje na zaprzeczenie, pozbawienie lub odwrotność tego, co nazywa drugi człon złożenia"”. Słownik PWN informację definiuje jako „to, co powiedziano lub napisano o kimś lub o czymś, także zakomunikowanie czegoś" ${ }^{5}$. W związku z powyższym jako dezinformację określamy zakomunikowanie czegoś, co nie jest zgodne ze stanem rzeczywistym, jako wprowadzanie kogoś w błąd.

Francuski publicysta, który w swym dorobku naukowym zasłynął jako teoretyk-specjalista od spraw dezinformacji i manipulacji świadomością, a mianowicie Vladimir Volkoff, dokonał rozróżnienia metod dezinformacji, wśród których wymienia: negację faktów, odwrócenie faktów, mieszanie prawdy i kłamstwa, modyfikację motywu i okoliczności, rozmycie, kamuflaż, interpretację, generalizację, ilustrację, nierówną i równą reprezentację ${ }^{6}$. Negacja faktów jest zabiegiem, w którym zakłada się, że głoszone informacje, które są nieprawdziwe, nie są możliwe do zweryfikowania, gdyż brak osoby (świadka), który mógłby zdementować powyższy przekaz. Podobnie w przypadku odwrócenia faktów, gdzie przedstawia się błędne informacje (tak zwane odwrócone fakty) z założeniem, że nie ma realnej możliwości na zweryfikowanie błędu. Negacja faktów oraz odwrócenie faktów jest stosunkowo rzadko wykorzystywaną metodą manipulacji, gdyż trudno jest o wystąpienie sytuacji, gdzie brakowałoby świadków czy innego odniesienia do rzeczywistości weryfikującego prawdziwość danych informacji.

Znacznie częściej wykorzystywane są pozostałe metody dezinformacji wskazane przez Volkoffa. Metoda dezinformacji polegająca na mieszaniu prawdy i kłamstwa stosowana jest wówczas, gdy odbiorca informacji posiada już część danych dotyczących jakiejś sytuacji i w procesie dezinformacji dostarczane są dodatkowe dane, które nie są zgodne z prawdą.

\footnotetext{
${ }^{3}$ A. Pepłoński, Wojna o tajemnice, Kraków 2011, s. 335.

${ }^{4}$ Dez-, https://sjp.pwn.pl/slowniki/dez-.html (25.08.2021).

${ }^{5}$ Ibidem.

${ }^{6}$ Za: A. Januszko-Szakiel, Dezinformacja jako narzędzie medialnej manipulacji świadomością, Warszawa 2010, s. 212.
} 
Modyfikacja motywu i okoliczności polega na udzieleniu odbiorcy takich informacji nieprawdziwych, które wpłyną na odbiór w tym względzie, że źle zostaną rozpoznane okoliczności lub motywy działania, niezgodnie $\mathrm{z}$ intencją działającego. Rozmycie jako metoda dezinformacji polega na tym, że obok faktów, zdarzeń istotnych przekazuje się cały szereg dodatkowych informacji, które mają za zadanie odwrócenie uwagi odbiorcy od istoty sytuacji, zdarzenia poprzez wprowadzenie chaosu informacyjnego. Podobną techniką dezinformacyjną jest kamuflaż, którego istotą jest także wprowadzenie chaosu informacyjnego oraz zakrycie tego, co istotne, poprzez zbytnie rozczłonkowanie problemu i podział zagadnienia na szereg informacji drobnych, nieistotnych. Interpretacja stosowana jest wówczas, gdy fakty są niezaprzeczalne. Dezinformacja przy zastosowaniu metody interpretacji polega na tym, że w taki sposób przedstawia się fakty, aby dzięki ich sposobie prezentacji były odczytywane przez odbiorcę w określony sposób, np. by odbiorca odczytał je pejoratywnie. Dzięki danej prezentacji faktów ma się zmienić ocena odbiorcy dotycząca danych informacji. Generalizacja ma spowodować, że dany fakt jednostkowy nie jest jedyny, wyjątkowy, unikatowy, ale dane fakty, zjawiska występują powszechnie, co zarazem zmienia rangę omawianego wydarzenia, sytuacji czy przekazywanej informacji na mniej doniosłą, mniej ważną. Ilustracja jest metodą, w której używa się przykładu zjawiska jednostkowego do ukazania szerszego zjawiska społecznego. Metoda nierównej reprezentacji stosowana jest często, gdy staje przed sobą dwóch oponentów. Wówczas osoba wykorzystująca dezinformację przerywa drugiej wypowiedź w połowie zdania, a następnie dopowiada, parafrazuje, streszcza, w taki sposób, aby przekazane informacje były z korzyścią dla niej, a nie osoby, z której ust wypłynęły. Równa reprezentacja stosowana bywa w tym momencie procesu dezinformacji, gdy wszelkie przekazane nieprawdziwe informacje uprawdopodobniły się u odbiorcy i jest on przekonany, że są prawdziwe. Wówczas zamyka się dyskurs poprzez podsumowanie, zebranie argumentów i ostateczne wskazanie, że dane informacje należy uznać za zgodne ze stanem rzeczywistym.

\section{DEZINFORMACJA W RÓŻNYCH DZIECINACH ŻYCIA}

Pojawienie się terminu „dezinformacja” po raz pierwszy wskazuje jego związek z polityką. Dezinformacja tym czasem może występować w różnych dziedzinach życia ludzkiego, zarówno w życiu społecznym, publicznym, jak i w życiu prywatnym. Pojawia się wszędzie tam, gdzie pojawiają się informacje niezgodne ze stanem rzeczywistym, wprowadzające kogoś w błąd, gdzie zostaje zniekształcana rzeczywistość. Informacje uznawane za fakty sensu stricte faktami nie są, a jedynie jako takie zostają przedstawiane. Faktem są jedynie zaistniałe stany rzeczy, które mają swe silne ugruntowanie w rzeczywistości. Dezinformacja polega na przekazywaniu informacji, które faktami nie są, a przedstawia się je jako fakty. Jest rodzajem zniekształcania rzeczywistości.

Termin „dezinformacja”, jak wskazano powyżej, pojawił się po raz pierwszy w świecie polityki, jako celowy sposób operowania informacją, który wprowadza przeciwników politycznych 
w błąd. Bardzo szybko dezinformacja rozpoczęła pojawiać się w innych dziedzinach życia ludzkiego, choć niekoniecznie pojawiało się to konkretnie słowo, co określone działania o charakterze dezinformacyjnym. Zabieg ten szczególnie sprawdza się w świecie polityki czy działań wojennych, ze względu na swe cele, co zostanie szczegółowo omówione w dalszej części niniejszej pracy.

Szczególnie popularnym jest zabieg dezinformacji w rzeczywistości mass mediów. Wraz z dezinformacją przekazywaną przez nie pojawiło się nowe pojęcie zwane „fake news”. Powyższy zwrot jest neologizmem oznaczającym - jak podaje Encyklopedia Internetowa Wikipedia - „nieprawdziwa lub częściowo nieprawdziwa wiadomość, często o charakterze sensacyjnym, publikowana w mediach z intencją wprowadzenia odbiorców w błąd" "7. Niekiedy dezinformacja w mediach uważana jest za celowe rozpowszechnianie alternatywnych faktów, czyli informacji, które nie mają odniesienia do rzeczywistości lub zniekształcają tę rzeczywistość. Jak podaje Bartłomiej Łódzki z Wydziału Nauk Społecznych Uniwersytetu Wrocławskiego w opracowaniu dotyczącym istoty ,fake news" ${ }^{8}$, do jego dystrybucji wykorzystuje się nie tylko mass media w postaci prasy, radia, telewizji, lecz także nowoczesne technologie oraz możliwości, jakie daje w obecnych czasach Internet.

Dezinformacja pojawia się także powszechnie w życiu prywatnym, jednakże wówczas obejmuje zwykle swym zasięgiem mniejszą grupę ludzi. Dotyczy ona rozpowszechniania nieprawdziwych informacji dotyczących osób, sytuacji, zdarzeń w środowiskach lokalnych. Zwykle bywa przekazem ustnym. Jednakże zamiast terminu „dezinformacja” używane są inne określenia na nazwanie niniejszego zjawiska, np. pomówienie, plotka, oszczerstwo, itp. Ten typ dezinformacji występuje od zarania dziejów i wynika z charakteru natury ludzkiej.

Dezinformacja jest zawsze pewnym procesem, w którym pojawia się osoba będąca sprawcą tej czynności oraz odbiorca czynności, informacja, podlegająca zniekształceniu, którą przedstawia się niezgodnie z rzeczywistością, oraz sam sposób przekazu, komunikacji. Bez powyżej wymienionych elementów nie można mówić o dezinformacji. Osobą przekazującą nieprawdziwe informacje zwykle jest podmiot pojedynczy, a odbiorcą zwykle bywa jakaś zbiorowość. Przykładowo osoba udzielająca wywiadu w mass mediach przekazuje nieprawdziwe informacje wprowadzając w błąd odbiorców, czyli osoby, do których dany komunikat jest skierowany. Oprócz informacji, czyli wypowiedzianych słów, pojawia się forma komunikacji, przekazu, czyli w danym przypadku wykorzystanie mass mediów.

W niniejszym artykule przyjrzymy się dokładniej dezinformacji w aspekcie prawno-kryminalistycznym, czyli w odniesieniu do rzeczywistości prawa oraz sytuacji, gdy to prawo zostaje naruszone. Należy zwrócić uwagę, że dezinformacja w aspekcie prawno-kryminalistycznym może być traktowana dwojako. Po pierwsze, dezinformację rozumie się jako świadome przekazywanie informacji niezgodnych z prawdą w postępowaniu w sprawach karnych. Po

\footnotetext{
${ }^{7}$ Fake news, https://pl.wikipedia.org/wiki/Fake_news (28.08.2021).

${ }^{8}$ Vide B. Łódzki, Fake news - dezinformacja w mediach internetowych i formy jej zwalczania w przestrzeni międzynarodowej, „Polityka i Społeczeństwo” 4(15)/2017, s. 19-30.
} 
drugie, dezinformacja w świetle 132 art. kodeksu karnego, czyli jako czyn podlegający karze. Oba te, skrajnie różne rozumienia pojęcia „dezinformacja”, pojawiają się powszechnie w rzeczywistości prawno-kryminalistycznej, o czym traktuje poniższa część artykułu.

\section{CEL DEZINFORMACJI}

Aby zrozumieć pojęcie dezinformacji w aspekcie prawno-kryminalistycznym konieczne jest przyjrzenie się celom, w jakich jest ono stosowane. Istotą dezinformacji, jak wspomniano powyżej, jest przekazanie nieprawdziwych informacji. Podstawą jednak tego działania jest cel, w jakim zostaje ono podjęte. Celem dezinformacji jest szeroko pojęta korzyść leżąca po stronie osoby, która stosuje niniejszy zabieg. Korzyść, czyli efekt dezinformacji, ma osobie dezinformowanej przekazać pewną wiedzę, która jest właściwie wiedzą pozorną, bo nie odnoszącą się do rzeczywistości lub zniekształcającą rzeczywistość, podczas gdy odbiorca niniejszej informacji ma żywić przekonanie, że otrzymana informacja jest zgodna z rzeczywistością, ze stanem faktycznym. Dzięki przekazowi danych informacji zniekształcających rzeczywistość osoba dezinformująca chce osiągnąć pewien założony sobie uprzednio cel. Cel jest tym, co wyznacza kierunek dezinformacji. Nieprawdziwe informacje przekazuje się zawsze w jakimś konkretnym celu, np. skłonienia osoby, której przekazuje się dane informacje, do podjęcia pewnych działań. „Dezinformacja nie jest prostym kłamstwem, czyli przekazaniem fałszywej informacji, jest podstępem"”. Podstęp wiąże się ze sprytem, który wykorzystywany jest w celu oszukania kogoś. Jednakże dezinformacja rozumiana jako podstęp kojarzy się raczej pejoratywie. Tymczasem dezinformację nie zawsze należy kojarzyć w ten sposób, gdyż istotny jest cel, jaki jej przyświeca.

Teoretyk pojęcia „,dezinformacja”, Mikołaj Juliusz Wachowicz, zauważa, że celem dezinformacji nie musi być zakrycie prawdy, ale stworzenie „szerokiego pola możliwości intelektualnych, by w umyśle przeciwnika doszły do głosu jego własne preferencje. Istotą dezinformacji jest danie przeciwnikowi argumentu, by wierzył w to, co chce wierzyć" ${ }^{10}$. W tym sensie dezinformację rozumie się jako sposób wywierania wpływu na podmiot dezinformowany, pojęcie to można zatem porównać $\mathrm{z}$ manipulacją.

\section{DEZINFORMACJA A MANIPULACJA}

Jak zauważono powyżej, dezinformacja to celowe wprowadzanie kogoś w błąd, aczkolwiek jest to zwykle czynność kierowana przez podmiot rozpowszechniający nieprawdziwe informacje. Podmiot poprzez rozpowszechnianie tychże informacji chce osiągnąć dla siebie określone cele, korzyści płynące ze strony osoby dezinformowanej. W działaniu tym pojawia się celowość oraz nakierowanie na korzyść, dlatego dezinformację w tym względzie można połączyć z manipulacją.

\footnotetext{
${ }^{9}$ T.R. Aleksandrowicz, Podstawy walki informacyjnej, Editions Spotkania, Warszawa 2016, s. 83.

${ }^{10}$ M.J. Wachowicz, Ujęcie teoretyczne pojęcia dezinformacji, Akademia Sztuki Wojennej, Warszawa 2013, s. 13.
} 
Manipulacja jest podejmowaniem czynności, których celem jest wpływanie na postępowanie innych osób. W czynności tej przekształca się rzeczywistość, aby osiągnąć wyznaczone sobie cele ${ }^{11}$. Niekiedy trudno jednoznacznie rozpoznać manipulację, ale tym, co ją wyróżnia, jest intencja osoby manipulującej, czyli uzyskanie pewnych korzyści dla siebie przez korzystanie $\mathrm{z}$ różnych technik wpływu na odbiorcę. Manipulacja nie jest stricte zbieżna z dezinformacją, gdyż techniki manipulacyjne to nie tylko przekaz informacji niezgodnych z prawdą, lecz także szereg innych czynności nie wchodzących w ramy procesu dezinformacyjnego. Ponadto „nie można (...) nazwać manipulatorem osoby, która dopuszcza się technik manipulacji, lecz nie jest tego świadoma"12, podczas gdy w przypadku dezinformacji osoby, które przekazują nieświadomie informacje niezgodne z rzeczywistością, także są dezinformatorami pomimo tego, że ich działanie nie jest celowe.

Reasumując, dezinformacja jest zbieżna z manipulacją tylko w tym względzie, że osoba przekazująca informacje niezgodne z rzeczywistością robi to świadomie i ma na celu wprowadzenie odbiorców tych informacji w błąd oraz wywołanie tym samym pewnych skutków korzystnych dla siebie. Jeśli pojawia się dezinformacja jako czynność nieświadoma, wówczas nie ma ona nic wspólnego z manipulacją. Co więcej, manipulacja wydaje się pojęciem szerszym, gdyż dezinformacja jest jedynie jedną z wielu technik manipulacyjnych.

\section{CEL DEZINFORMACJI W ASPEKCIE PRAWNO-KRYMINALISTYCZNYM}

$\mathrm{W}$ aspekcie prawno-kryminalistycznym celem dezinformacji w trakcie postępowania karnego zwykle jest potrzeba organów ścigania, aby określone informacje prawdziwe czy nieprawdziwe stały się ogólnie dostępne tak, aby miało to pozytywny wpływ na prowadzone dochodzenie lub śledztwo. Liczy się efekt prowadzonej sprawy, czyli zebranie odpowiednich materiałów dowodowych, ich analiza oraz wydanie wyroku. Część informacji w trakcie śledztwa jest utajniona, pojawia się jednak potrzeba przekazania do opinii publicznej pewnych informacji niezgodnych z rzeczywistością, aby w ten sposób usprawnić tok czynności dochodzeniowośledczych. Wydawałoby się, że dezinformacja posiada pozytywny wydźwięk, podczas gdy przyświecają jej szczytne cele, np. szybsze doprowadzenie danej sprawy do jej trafnego zakończenia. Dla lepszego zrozumienia sposobu funkcjonowania dezinformacji jako z pozoru pozytywnego elementu w rzeczywistości prawno-kryminalistycznej temat ten zostanie omówiony na przykładach w dalszej części niniejszego artykułu.

Jeśli przekazanie nieprawdziwych informacji do wiadomości publicznej jest kontrolowane, można by się pokusić o pozytywną ocenę zjawiska dezinformacji (zagadnienie to zostanie szczegółowiej opisane w dalszej części artykułu). Jednakże jej cel może być także zupełnie inny, wówczas może wyrządzić więcej szkód niż korzyści w toku prowadzonego postępowania. Przykładowo,

\footnotetext{
${ }^{11}$ Za: J. Hernik, Informacja, czy manipulacja? Analiza na przykładzie wybranych reklam [w:] „Zarządzanie XL”, zeszyt 413, Torun 2013, s. 197-198.

12 Ibidem, s. 197.
} 
gdy do środków masowego przekazu trafia informacja, która nie jest prawdą, a zarazem wywołuje chaos czy inne negatywne skutki mające wpływ na podejmowane czynności przez organy ścigania. Wówczas ten typ dezinformacji należy ocenić zdecydowanie negatywnie.

Należy zauważyć, że niekiedy dezinformacja jest celowym działaniem, ale zdarzają się również przypadki, że w związku z postępowaniem prowadzonym przez organy ścigania pewne informacje prawdziwe lub fałszywe trafiają za pośrednictwem mass mediów do wiadomości publicznej bez zgody czy nawet wiedzy osoby prowadzącej sprawę. Informacja taka zwykle ma niepożądane konsekwencje w aspekcie prawno-kryminalistycznym. Podobnie, jak wspomniana powyżej dezinformacja celowa, jest zagrożona konsekwencjami prawno-kryminalistycznymi, w zależności od wagi danej informacji oraz chaosu informacyjnego, jaki wywołuje.

Dezinformacja może mieć ogromną moc sprawczą, gdyż na tyle potrafi wpłynąć na odbiór społeczny, że opinia publiczna przyjmie pewne informacje za fakty, ze względu na sposób ich przedstawienia, nawet gdy faktami nie będą. Wydawane są wówczas kolejne błędne oceny rzeczywistości, co w aspekcie prawno-kryminalistycznym może oznaczać, że opinia publiczna uzna daną osobę za winną zarzucanego czynu przed wydaniem prawomocnego wyroku.

Wokół pojęcia dezinformacji rozważanego w aspekcie prawno-kryminalistycznym pojawiają się kontrowersje, gdyż wydawałoby się, że w myśl zasady Niccolo Machiavellego brzmiącej „cel uświęca środki” można by usprawiedliwić celowe wprowadzanie w błąd poprzez organy ścigania, jeśli ma się to przysłużyć szczytniejszymi celom, jakim jest np. pomoc w rozwiązaniu sprawy kryminalnej. Tymczasem zgodnie z przyjętymi powyżej definicjami dezinformacji należy oceniać ją zdecydowanie negatywnie, nawet w przypadku, gdy wydawałoby się, że temuż działaniu przyświecają szczytne cele. Kontrolowana dezinformacja, niezależnie od jej celów, jest bardziej nieetyczna, ponieważ ma z założenia cel manipulacyjny, podczas gdy niekontrolowana dezinformacja jest przypadkowa i nieprzewidywalna w skutkach przez twórcę informacji.

Dezinformacja w aspekcie prawno-kryminalistycznym to przekaz zafałszowanych informacji pochodzący od różnych stron i stosowany w różnym celu. Wówczas ocena procesu dezinformacyjnego pod kątem jego użyteczności czy skutków zależna jest od wielu czynników składowych, a przede wszystkim od konsekwencji, jakie za sobą niesie dany przekaz dezinformacyjny. Ocena procesu dezinformacji pod kątem etyczności wskazuje zdecydowanie na negatywny odbiór tego procederu, na co także wskazują przytoczone powyżej definicje dezinformacji autorstwa Volkoffa oraz Wachowicza przyjęte na potrzeby niniejszej pracy.

Jednakże o dezinformacji w rzeczywistości prawno-kryminalistycznej można także mówić w odniesieniu do art. 132 kodeksu karnego, co przedstawiono poniżej. 


\section{DEZINFORMACJA W ŚWIETLE ARTYKULU 132 K.K.}

Artykuł 132 k.k. brzmi: „Kto, oddając usługi wywiadowcze Rzeczpospolitej Polskiej, wprowadza w błąd polski organ państwowy przez dostarczanie podrobionych lub przerobionych dokumentów lub innych przedmiotów albo przez ukrywanie prawdziwych lub udzielanie fałszywych wiadomości mających istotne znaczenie dla Rzeczpospolitej Polskiej, podlega karze pozbawienia wolności od roku do lat 10"13. Przestępstwa popełnione w odniesieniu do art. 132 k.k. związane są z ochroną interesów organizacji państwowej. Artykuł ten odnosi się stricte do osób świadczących usługi wywiadowcze. Należy podkreślić, iż w czasie pokoju wywiad jest szczególnie istotnym elementem w strategii funkcjonowania państwa.

Piotr Chlebowicz, zajmujący się interpretacją pojęcia dezinformacja w świetle art. 132 k.k., zwraca uwagę na analizę i specyfikę podmiotu, do jakiego dany artykuł Kodeksu Karnego się odnosi ${ }^{14}$. Chlebowicz dostrzega, że art. 132 k.k. traktuje o dezinformacji wywiadowczej, więc podmiotem, do którego się odnosi, jest pracownik służb specjalnych, związanych z wywiadem, który poprzez przekazanie fałszywych informacji, zatajanie prawdziwych lub posługiwanie się świadomie podrobionymi lub przerobionymi dokumentami działa na niekorzyść państwa polskiego. Podmiot przestępstwa jest dokładnie scharakteryzowany i nie odnosi się do każdej osoby, lecz do wybranej grupy osób, wykonujących określony zawód. Odnośnie do czynności sprawczych ich katalog jest szczegółowo określony w omawianym artykule. Dezinformacja w sferze politycznej podlega karze pozbawienia wolności do lat 10. Tak pojęta dezinformacja, na co wskazuje chociażby dolegliwość kary, jest pojęciem zdecydowanie negatywnym oraz zjawiskiem niepożądanym w rzeczywistości prawno-kryminalnej. Dezinformacja jako działanie na niekorzyść państwa polskiego jest niepożądana i rodzi skutki prawne. Co więcej, jeśli sprawa regulowana jest na mocy kodeksu karnego, jak to jest w przypadku dezinformacji politycznej jako przestępstwa z art. 132 k.k., wówczas niesie to za sobą określone skutki prawne dla podmiotu dopuszczającego się danego przestępstwa. Skutkiem jest sankcja, a także wpis do Krajowego Rejestru Karnego, który posiada swe umocowanie prawne w Ustawie z dnia 24 maja 2000 r. o Krajowym Rejestrze Karnym ${ }^{15}$, a prowadzonym przez Ministerstwo Sprawiedliwości.

\section{KONTROWERSJE WOKÓŁ DEZINFORMACJI W ASPEKCIE PRAWNO-KRYMINALNYM}

W odniesieniu do dezinformacji w rozumieniu artykułu 132 k.k. oczywistym wydaje się, że należy oceniać ją pejoratywnie jako działanie na szkodę państwa polskiego, gdzie trudno wskazać pozytywne cechy takiegoż zachowania, które na mocy kodeksu karnego podlega karze.

\footnotetext{
${ }^{13}$ Art. 132 [w:] Ustawa z dnia 6 czerwca 1997 r. Kodeks Karny (Dz. U. 1997 nr 88 poz. 553).

14 Vide P. Chlebowicz, Interpretacja pojęcia dezinformacji $w$ świetle art. 132kk, „Studia Prawnoustrojowe”, nr 15/2012, s. 41-48.

${ }^{15}$ Vide Ustawa z dnia 24 maja 2000 r. o Krajowym Rejestrze Karnym (Dz. U. 2000 nr 50 poz. 580) . 
Jednakże rozumiejąc dezinformację jako przekaz wiadomości niezgodnych z prawdą, które wypływają od strony organów ścigania, a kierowane są do powszechnego odbioru, do wiadomości publicznej, wówczas - mimo zafałszowania rzeczywistości i negatywnej oceny tegoż procederu z tego typu działań dezinformacyjnych mogą płynąć także wymierne korzyści.

Ważną rolę w procesie dezinformacyjnym w aspekcie prawno-kryminalistycznym odgrywają mass media, które mają ogromny wpływ na opinię publiczną. Z jednej strony organy ścigania $\mathrm{w}$ toku prowadzonego postępowania celowo przekazują informacje prawdziwe lub zniekształcone do informacji publicznej, aby osiągnąć dzięki temu wymierne korzyści. Z drugiej jednak strony mass media oraz przestrzeń publiczna jest żądna informacji dotyczących wydarzeń z dziedziny prawno-kryminalistycznej. Niekiedy potrzeba przekazu i potrzeba odbioru wzajemnie uzupełniają się, a niekiedy dochodzi na tej płaszczyźnie do wyraźnego konfliktu.

Wokół pojęcia dezinformacji w aspekcie prawno-kryminalistycznym pojawia się szereg kontrowersji. Z jednej strony organy ścigania za pomocą mass mediów przekazują do informacji publicznej szereg informacji niezgodnych z rzeczywistością czy przekłamanych, z drugiej zaś strony wydawałoby się, że odbiorcy tych informacji powinni otrzymywać rzetelne fakty, zgodne z rzeczywistością, gdyż mają prawo znać prawdę, zamiast obracać się w sferze nieprawdy i rzeczywistości zniekształconej przez przekłamania. Przekaz informacji w trakcie prowadzonego postepowania w sprawach karnych może zakłócać prowadzone czynności. Wydaje się, że dochodzi do wyraźnego konfliktu pomiędzy wolnością środków masowego przekazu, znajdującą swe umocowanie w art. 54 Konstytucji Rzeczypospolitej Polskiej, a potrzebą utajnienia pewnych informacji konieczną $\mathrm{w}$ toku spraw prowadzonych przez organy ścigania. Art. 54 Konstytucji RP brzmi: „Każdemu zapewnia się wolność wyrażania swoich poglądów oraz pozyskiwania i rozpowszechniania informacji"16. Na mocy powyższego przepisu społeczeństwo ma prawo do otrzymywania informacji. Ponadto przekaz informacji także nie może być utrudniany. $Z$ drugiej jednak strony przekazywane informacje oraz ich odbiór społeczny mogą wprowadzić chaos czy utrudnienia w czynnościach podejmowanych przez organy ścigania. Ponadto informacje świadomie oraz nieświadomie mieszane bywają z dezinformacjami, co wprowadza kolejne zamieszanie w przekazie. Potrzeby odbiorców oraz nadawców bywają skrajnie różne, a tym bardziej interesy obu stron. Często ktoś bywa poszkodowany przez przekaz wiadomości dezinformacyjnych. W rzeczywistości prawno-kryminalistycznej toczą się sprawy dotyczące życia ludzkiego, gdzie przekaz dezinformacyjny może nieść za sobą szereg negatywnych konsekwencji. Aczkolwiek dezinformacja pojawiająca się w mass mediach stanowiąca świadome działanie organów ścigania może przynosić także i pozytywne konsekwencje dla toku postępowania. Zarówno w teorii, jak i w praktyce widoczne jest występowanie szeregu kontrowersji wokoło pojęcia „dezinformacja” rozpatrywanego w aspekcie prawno-kryminalistycznym, z wyłączeniem przypadku omówionego powyżej, gdy pojęcie „dezinformacja” rozpatrywane jest w myśl art. 132 k.k.

\footnotetext{
${ }^{16}$ Konstytucja Rzeczpospolitej Polskiej z dnia 2 kwietnia 1997 r. (Dz. U. 1997 nr 78 poz. 483).
} 
W praktyce, na przestrzeni lat pojawił się szereg spraw, w których dezinformacja odegrała bardzo ważną rolę. Warto podkreślić, że słynne sprawy karne to nie tylko ogrom pracy organów ścigania utrudnianej niekiedy przez pracę mass mediów, lecz także prawdziwe spektakle sądowotelewizyjne, którymi żyje spora część społeczeństwa żądnego coraz to nowych informacji.

Rozpatrując pojęcie dezinformacji w kontekście prawno-kryminalistycznym na przykładach nie sposób nie wspomnieć o słynnej sprawie zabójstwa półrocznej dziewczynki, Magdaleny Waśniewskiej w Sosnowcu w dniu 24 stycznia 2012 roku. Sprawą śmierci dziecka zainteresowane były mass media oraz opinia publiczna. Początkowo matkę Magdaleny postrzegano jako ofiarę, współczując jej utraty dziecka. W sprawę zaangażowane były organy ściągania oraz instytucje zewnętrzne, w tym słynny przedsiębiorca prowadzący Agencję Detektywistyczną, Krzysztof Rutkowski. Do matki, która utraciła córkę, podchodzono z empatią, współczuciem poszukując sprawcy. W mediach pojawił się szereg nowych informacji mniej lub bardziej osadzonych w rzeczywistości - poszukiwano sprawcy oraz roztrząsano tragedię, jaka dotknęła matkę zmarłej. Z kobiety początkowo zrobiono ofiarę, osobę poszkodowaną, której trzeba współczuć. Zyskała ona ogromne wsparcie ze strony społeczeństwa, gdy mass media przedstawiły ją jako cierpiącą kobietę po stracie sześciomiesięcznego dziecka. Tymczasem realia okazały się zupełnie inne. W toku śledztwa ustalono, że winną śmierci dziecka jest sama matka, która z premedytacją zabiła własną córkę. Kobietę skazano na 25 lat więzienia, z możliwością przedterminowego zwolnienia po 20 latach odbywania kary.

Na przykładzie powyżej opisanej sprawy ukazano, jak wielką moc sprawczą ma przekaz informacji. Podczas gdy przekazywano informacje, zarówno te prawdziwe i fałszywe dotyczące poszukiwania sprawcy oraz cierpienia matki, która straciła córkę, media oraz opinia publiczna pozytywnie wypowiadały się o kobiecie podkreślając emanujące cierpnie, poczucie straty powiązane ze współczuciem. Gdy w toku śledztwa ustalono inny fakty, niż zakładano dotychczas, wizerunek kobiety oraz jej odbiór uległ natychmiastowej zmianie w obiorze społecznym. Najwięcej dezinformacji pojawiało się $\mathrm{w}$ toku prowadzonego śledztwa, gdy stacje telewizyjne i radiowe oraz prasa prześcigały się w podawaniu coraz to nowych, niezweryfikowanych wiadomości. W takich sytuacjach liczy się ilość przekazanych nowych informacji, a nie ich jakość, dlatego też dochodzi wówczas do chaosu informacyjnego, co daje doskonałe miejsce do pojawiania się dezinformacji. Sprawa zabójstwa Magdaleny Waśniewskiej tym bardziej dała możliwość pojawiania się wiadomości dezinformacyjnych, gdyż w toku prowadzonego śledztwa pojawiały się coraz to nowe hipotezy oraz przewidywalne scenariusze rozwiązania niniejszej sprawy. Ograny ściągania podawały do informacji publicznej szczątkowe wiadomości dotyczące faktów, a mass media podejmowały próby interpretacji czy poszukiwania nowych wiadomości, co stwarza ogromne możliwości dla pojawiania się fake newsów oraz dezinformacji.

Przykładem sprawy, gdzie w wyniku dezinformacji doszło do skazania niewinnej osoby, jest sprawa Tomasza Komendy. W noc sylwestrową 1996/1997 doszło do brutalnego gwałtu na piętnastoletniej Małgorzacie Kwiatkowskiej, w którego wyniku dziewczyna zmarła. 
W trakcie poszukiwania sprawców pewna kobieta poinformowała, że na wskazanym zdjęciu podejrzanych rozpoznaje swojego sąsiada Tomasza Komendę. Mężczyzna został aresztowany, następnie na podstawie poszlak skazany, przy czym, co ujawniono po latach, znęcano się nad nim w trakcie śledztwa, aby przyznał się do winy. Organy ściągania zainteresowały się mężczyzną wyłącznie z powodu informacji uzyskanej od jego sąsiadki, chociaż informacja ta okazała się nieprawdziwa. Tomasz Komenda został skazany na 25 lat pozbawienia wolności, po czym po 18 latach odbywania kary został warunkowo zwolniony, a następnie uniewinniony. Niniejszy przykład wskazuje na to, jakie poważne, negatywne skutki mogą płynąć z jednej informacji niezgodnej z rzeczywistością, a przekazanej jako prawdziwa w rzeczywistości prawno-kryminalistycznej. Ze względu na to, że wskazano akurat tego mężczyznę, który ze sprawą nie miał nic wspólnego, niewinny człowiek spędził osiemnaście lat w zakładzie karnym za przestępstwo, którego nie popełnił. Jedna wiadomość dezinformacyjna pociągnęła za sobą szereg następnych zdarzeń. Jak widać, konsekwencje dezinformacji w odniesieniu do prowadzonego dochodzenia lub śledztwa mogą mieć daleko idące oraz krzywdzące skutki w świecie rzeczywistym.

W trakcie spraw toczonych przed sądem osoby obwinione czy oskarżone wielokrotnie także stosują techniki dezinformacyjne w celu uniknięcia kary. Osoba, której są postawione zarzuty, ma prawo odmówić składania zeznań lub mówić przed sądem nieprawdę. Przez przekazywanie informacji nieprawdziwych osoba obwiniona czy oskarżona wprowadza chaos, utrudnia czynności procesowe, jednakże często jest to metodą obrony, podobnie jak inne zabiegi jak informowanie o utracie wybiórczej pamięci czy sprowadzanie postępowania na niewłaściwe tory.

Nawiązując do metod dezinformacji wymienianych przez Volkoffa osoby, wobec których toczy się postępowanie karne, wymiennie korzystają z kilku wyróżnionych metod, a najczęściej z odwrócenia faktów, mieszania prawdy i kłamstwa, modyfikacji motywu i okoliczności, rozmycia, kamuflażu, interpretacji. Przykładem zastosowania metod dezinformacyjnych przez osobę oskarżoną jest słynna sprawa medialna dotycząca Ewy Tylman. W listopadzie 2015 roku w godzinach nocnych Ewa Tylman w obecności swojego kolegi Adama wyszła z integracyjnej imprezy firmowej. Kobieta nie wróciła do domu (zaginęła). W lipcu 2016 roku wyłoniono jej ciało z pobliskiej rzeki. Śledczy ustalając przebieg zdarzeń, w których doszło do śmierci kobiety, przesłuchiwali jej kolegę Adama. Mężczyzna zmieniał kilkakrotnie swą wersję wydarzeń lub twierdził, że stracił wybiórczo pamięć, co utrudniało ustalenie prawdy. Ostatecznie mężczyźnie postawiono zarzuty spowodowania śmierci Ewy Tylman. Sąd Okręgowy uniewinnił mężczyznę, następnie Sąd Apelacyjny przywrócił sprawę do ponownego rozpatrzenia. Sprawa obecnie jest w toku. W związku z chaosem, jaki zapanował po sprzecznych wyjaśnieniach składanych przez Adama, trudno jednoznacznie zrelacjonować przebieg zdarzeń związanych ze śmiercią Ewy Tylman. Dezinformacja, która wyszła z ust oskarżonego, odegrała w niniejszej sprawie ewidentnie negatywną rolę. 
Szczególnie bulwersującą sprawą, która jest doskonałym przykładem, jaką rolę odgrywa proces dezinformacyjny w systemie orzekania sądowego, jest sprawa czteroletniego chłopca o imieniu Michał, który został utopiony w rzece. Sąd zarzuty spowodowania śmierci przedstawił Robertowi K., który był konkubentem matki chłopca, oraz jego koledze Danielowi S. Mężczyźni w toku postępowania składali różne wyjaśnienia, co do przebiegu zdarzeń - raz przyznawali się do morderstwa, a innym razem twierdzili, że był to nieszczęśliwy wypadek. Przez swą postawę próbowali lub dążyli do uniewinnienia lub złagodzenia kary wprowadzając chaos informacyjny przez stosowanie metod dezinformacji. W toku postępowania Robert K. poinformował, że przestępstwo zostało popełnione na prośbę matki dziecka, czyli Barbary S. Kobiecie postawiono zarzuty. $\mathrm{W}$ trakcie rozpatrywania tej bardzo medialnej sprawy opinia publiczna wydała własny wyrok pejoratywnie oceniający kobietę jako wyrodną matkę oraz dzieciobójczynię. Przesłuchano szereg świadków, którzy wydali bardzo zróżnicowaną opinię na temat Barbary S. jako matki. Nagonka medialna oraz zeznania współoskarżonych przyczyniły się do wydania wyroku skazującego. Kobieta od początku postępowania twierdziła, że jest niewinna, tymczasem została skazana przez sąd pierwszej instancji na 25 lat więzienia, podczas gdy prokurator wnosił o dożywocie. Sąd Apelacyjny skierował sprawę do ponownego rozpatrzenia. Ostatecznie po siedmiu latach od popełnienia zbrodni Barbara S. został uniewinniona. Przykład tej sprawy wskazuje na to, jak duży wpływ na wydanie wyroku może mieć chaos informacyjny. Sprawa była analizowana przez kilka lat i Sąd Apelacyjny wydał zupełnie różny wyrok niż sąd pierwszej instancji. Gdyby w toku postępowania sądowego nie pojawiały się działania dezinformacyjne, szybciej i sprawniej udałoby się dotrzeć do obrazu stanu faktycznego, a tym samym do zakończenia sprawy.

Przytoczone wyżej przykłady wskazują, jak ważną rolę odgrywa zagadnienie dezinformacji w rzeczywistości prawno-kryminalistycznej. Można wymienić szereg przykładów, w których proces dezinformacji odgrywał istotną rolę w przebiegu postępowania czy nawet miał nań decydujący wpływ. Dlatego też wydaje się uzasadnionym stwierdzenie, że wokoło pojęcia dezinformacji w aspekcie prawno-kryminalistycznym pojawia się szereg kontrowersji.

\section{Podsumowanie}

Pojęcie „dezinformacji” jako neologizm doczekało się dość obszernego opracowania teoretycznego. Takie zainteresowanie dezinformacją wynika z jej użyteczności w różnych dziedzinach życia, szczególnie w czasach współczesnych, gdy światem rządzi technologia, cyfryzacja, w którym wszelkie dane i informacje są cennym źródłem dochodu. Dezinformacja pojawia się zarówno w życiu prywatnym, jak i publicznym. Szczególnego znaczenia jednak nabrała w aspekcie prawno-kryminalistycznym, gdzie ma ogromny wpływ na przebieg postępowania dowodowego, a nawet na kształt postanowień, a tym samym na ludzkie życie.

Niniejszy artykuł zrealizował założony cel poprzez szczegółową analizę pojęcia dezinformacji $\mathrm{w}$ różnych jej zastosowaniach w aspekcie prawno-kryminalistycznym, wraz 
z ukazaniem teorii oraz praktyki tegoż zjawiska. Problem badawczy pozostał rozstrzygnięty w oparciu o rozważania teoretyczne oraz adekwatnie przytoczone przykłady. Ukazano różne przykłady zastosowania pojęcia dezinformacja w aspekcie prawno-kryminalistycznym zarówno w sferze teoretycznych dywagacji, jak i w sferze praktyki życia codziennego.

\section{BIBLIOGRAFIA}

Aleksandrowicz Tomasz R. 2016. Podstawy walki informacyjnej. Warszawa: Editions Spotkania.

Chlebowicz Piotr. 2012. „Interpretacja pojęcia dezinformacji w świetle art. 132kk”. Studia Prawnoustrojowe 15/2012: 41-48.

Grzesiuk Kalina. Metodyka badań naukowych W https://pracownik.kul.pl/files/12359/public/grzesiuk/seminarium/metodyka_badan_naukowych.pdf

Hernik Joanna. 2013. „Informacja, czy manipulacja? Analiza na przykładzie wybranych reklam”. Zarządzanie XL zeszyt 413: 193-204.

Januszko-Szakiel Aneta. 2010. Dezinformacja jako narzędzie medialnej manipulacji świadomością. Warszawa: Wydawnictwo Oficyna.

Konstytucja Rzeczpospolitej Polskiej z dnia 2 kwietnia 1997 r. (Dz. U. 1997 nr 78 poz. 483).

Łódzki Bartłomiej. 2017. „Fake news - dezinformacja w mediach internetowych i formy jej zwalczania w przestrzeni międzynarodowej”. Polityka i Społeczeństwo 4(15): 19-30.

Pepłoński Andrzej. 2011. Wojna o tajemnice. Kraków: Wydawnictwo Literackie.

Słownik Języka Polskiego W www.sjp.pwn.pl

Ustawa z dnia 6 czerwca 1997 r. Kodeks Karny (Dz. U. 1997 nr 88 poz. 553).

Ustawa z dnia 24 maja 2000 r. o Krajowym Rejestrze Karnym (Dz. U. 2000 nr 50 poz. 580).

Wachowicz Mikołaj J. 2013. Ujęcie teoretyczne pojęcia dezinformacji. Warszawa: Akademia Sztuki Wojennej. 